\title{
LAND TENURE SYSTEM: WOMEN'S ACCESS TO LAND IN A COSMOPOLITAN CONTEXT
}

\author{
Eva Seraphim Tandoh Quansah* \\ http://dx.doi.org/10.4314/og.v9i1.8
}

\section{Abstract}

Land tenure is a concept that looks at how people gain access to land and how they make use of it. In various African societies, there are cases where women's land ownership is complicated by the gender ideology that women should not own property, particularly land and housing. Women who own property tend to be stereotyped as self-assertive and unruly, and therefore not marriage worthy. This study utilized primary data and combined quantitative and qualitative methods in analyzing the data collected. Focused group discussions (FGDs) were also organized as a source of qualitative information to support the quantitative data. Findings from the research are that there is an increase in net registration of titles to land by males over the period, compared to a reduction in females registering titles. There is a gender difference in the number of plots owned by males and females. Males owned more plots of land as compared to females. While the majority of male respondents directly negotiated for their land purchases, it was more usual for females to use male intermediaries in an effort to prevent being duped by predominantly male land sellers. Recommendation from the study is that equal inheritance rights to land should be guaranteed to both men and women.

\section{Introduction}

Land is highly valued in all African societies and has many rules and rituals governing its holding and use (Sarpong, 1974). Land is also of prime importance in shaping the 
Quansah: Land Tenure System \& Women's Access to Land

identity, integrity, solidarity and culture of any group of people (Quarcopoome, 1992). According to Lastarria-Cornhiel and Frais (2009), land represents an important cultural resource, a productive factor and capital asset, and those who control rights to land have a certain amount of power over those who do not, especially in rural agrarian economies.

Generally, the land tenure system in Africa and Ghana in particular is such that, land use and its control in the precolonial era and post-colonial era was mostly in the hands of men. In sub-Saharan Africa, the dominant land tenure system has been the customary/communal land tenure (Baden, Green, Otoo-Oyortey \& Peasgood, 1994; Kameri-Mboti, 2005). In the traditional Ghanaian society this communal tenure is of two types; stool land, which is controlled by the chief or king; and family land, which is in the hands of lineage heads (known as abusuapanyin among the Akans). In these two systems, control of land is still vested in male heads, even among societies that practice matrilineal inheritance. Decision-making over land at the community level tends to be dominated by male village chiefs, spiritual leaders (known as tindanas in Northern Ghana), and elders or heads of clans. Women therefore have limited access to, and control over, resources such as land in Ghana.

There are various obstacles in society that prevent women from owning their own property. Ntege (1993) explain that in various African societies, there are cases where women's land ownership is complicated by the gender ideology that women should not own property, particularly land and housing. Women who own property tend to be stereotyped as self-assertive and unruly, and therefore not marriage worthy. This belief may discourage women from buying land and/or pursuing their inheritance rights. For example, it is said that in Uganda, as far as women are concerned, house ownership is for the helpless - those who 
Ogirisi: a new journal of African studies vol 92012 will never marry, widows, prostitutes, senior spinsters and divorcees

IFAD (2001) has reviewed the situation of the barriers that account for women's control over land. From this research conducted in a rural agrarian society, it is easier to shift education, health and non-farm assets to women than to give them land rights. The basic reason for this is power. Outsiders may see education and health as important assets, but in rural communities, land counts more. Land gives social and economic power and the impact can be almost immediate. Therefore, giving women land means giving them power. It is not surprising that women have such a hard time obtaining control of this valuable asset.

Research in Kenya (Nzioki, 2009; Kameri-Mboti, 2005) confirms that land determines the economic well-being, social status and political power of individuals in a society. The Kenyan government has pursued programmes to transform customary land tenure into statutory freehold tenure through land adjudication, consolidation and registration (privatization). But the problem has been that the land titles are being transferred almost exclusively to individual men, thereby leaving no provision on how women's access rights are to be defined and how women will realize the goals of privatization once the lands are registered in the names of individual males. In this case, land titling has not only increased men's control over land distribution, but has also increased women's dependency on men.

This issue of land being registered in the names of males is not only prevalent in Kenya. Qvist (1995) outlined gender issues in relation to land in Egypt. As Egypt is an Arab Muslim country, its laws and cultural background are highly influenced by Islamic rules. In theory, women and men have equal rights to land tenure and property ownership in Egypt. Nevertheless, traditional structures play effective role and 
continue to discriminate against women. Qvist explains that ownership rights in Egypt are governed by the civil law and this law is neutral to gender. Customary law, on the other hand, opposes the equality of rights between men and women. Within customary law, the father is regarded as the head of the family and the inheritance right is favourable to children of the male sex. Women have the tendency of losing their identity as a result of their dependent social status, where women have to rely on the male figure in the family, be it father, husband, son or brother. Though ownership of property is becoming more common for Egyptian women, the majority of properties are registered in the father's or the husband's name. It does not matter whether the property was bought by the woman with her own funds. It is evident that, according to tradition and religion, contracts and leases should be managed by the husband. The refusal to do so could be considered as lack of trust or disrespect to her husband. In this study, the names in which land titles are registered in the Cape Coast Metropolis would be explored. This would be to find out whether what pertains to Egypt might be experienced in Ghana and for that matter in the cape Coast Metropolis.

Ghanaian cultural and ethnic diversity makes generalization about gender relations and their consequences on women's access to resources and decision making very difficult. The three northern regions and some societies in the southern regions are more likely to be disadvantaged due to factors like less urbanization and the less provision of social services and amenities. These factors combine with strong patriarchal family structures influence women's decision making in the society.

In many communities, the lineage authorities allocate land to the male household head. Women on the other hand have secondary cultivation rights that they obtain through male family members (Sarpong, 2006; Bortei-Doku, 2002). In 
Ogirisi: a new journal of African studies vol 92012 general therefore, the hierarchical nature of rights and responsibilities over land that emerge as a result of gender differentiated rights and roles are skewed against women and girls in favour of men and boys.

\section{Methodology}

Two different data sources were used, a survey of University of Cape Coast workers and selected landowners in the Cape Coast Metropolis. These were the sources of quantitative data for the research. Two focus group discussions were organized. There was also an in-depth interview of a land broker. These two sources of data also provided qualitative data for the research. The qualitative data served as further explanations of issues raised from the quantitative data. The survey of the University of Cape Coast workers comprised 272 respondents, out of whom $138(51 \%)$ owned land. The other source of survey data was 197 landowners selected from four newly developed residential areas in the Metropolis. Data collected from University of Cape Coast workers and selected residential landowners in the study area were combined and analyzed to obtain the factors that motivate both men and women to own land.

\section{Findings}

The obvious source of land acquisition by the respondents is through purchase, but a few people inherit land. More men inherit land from parents than females while only females inherit some land from spouses. Almost all the lands of the respondents were purchased, confirming the notion that land has become a commoditized commodity. Access to land in urban areas is mostly through buying and selling. From the survey, both men and women have bought more lands as compared to inherited lands. The implication is that more communal lands will be converted into private land ownership. 
Quansah: Land Tenure System \& Women's Access to Land

This will give men more privileges to the control of land than women since more men are buying more lands than women.

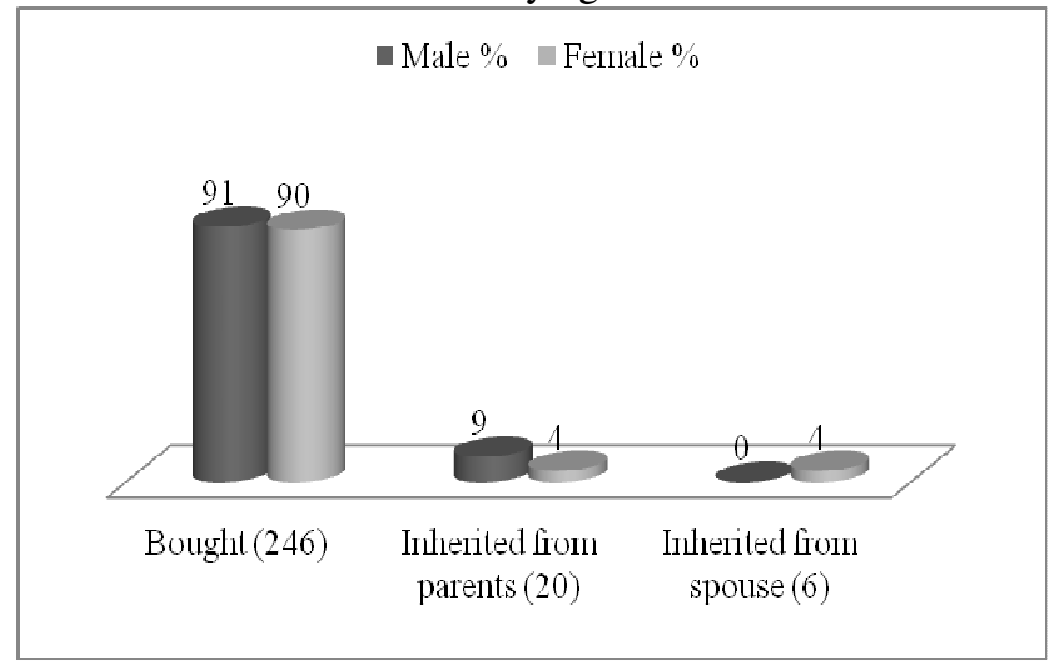

\section{Figure 1: Mode of land acquisition in the Metropolis}

Data source: Field Survey, January-July 2009

As the gap between men and women over land title holding begins to close up, it is hoped that women will also share in the economic power that were solely held by men in agrarian societies in the past. Men and women can therefore take decisions in relation to land matters in the society. This can create a stand for gender equality in the society and go some way in empowering more women.

Table 1 is a representation of gender and land title registration in the Metropolis. From the survey, it is clear that more women than men had registered their lands. In a follow up focus group discussion on why more women than men registered their lands, some of the reasons given were that women were generally more conscious of their vulnerability while many men could afford to be slack and not care. Men 
Ogirisi: a new journal of African studies vol 92012 were also said to be courageous compared to women and not afraid to go through litigation associated with land.

\section{Table 1: Gender and land title registration}

Male (\%) Female (\%) Total

$(\%)$

\begin{tabular}{|c|c|c|c|}
\hline $\begin{array}{l}\text { Registration } \\
\text { completed }\end{array}$ & $84(47)$ & $48(51)$ & $132(48)$ \\
\hline $\begin{array}{l}\text { Registration in } \\
\text { progress }\end{array}$ & $31(18)$ & $22(23)$ & $53(20)$ \\
\hline Not registered & $62(35)$ & $25(26)$ & $87(32)$ \\
\hline Total & $177(100$ & $95(100)$ & $272(100)$ \\
\hline
\end{tabular}

Data source: Field Survey, January-July 2009

The gender implication of this data in the Cape Coast Metropolis is that, women are more advantaged on this issue since women are more vulnerable, as they have had the courage to register their lands to create a safety net against litigation and family disputes.

Table 2 shows the land title registration of respondents. It may not be surprising that a large proportion of the lands bought by females have been registered in the names of their spouse or jointly with spouses. This practice is a replica of what happens in other African countries. In Kenya Nzioki (2009) has noted that titled lands were transferred almost exclusively into the names of individual men as the government changed customary land tenure to statutory tenure. When women register their lands in their husbands' names, it increases men's control over the ownership of land, thereby 
Quansah: Land Tenure System \& Women's Access to Land

also increasing women's dependence on men. Agarwal (1994) had also found out that in some African countries, joint titles with husbands present problems for women. For instance, women often find it difficult to gain control over the produce from the land to bequeath the land as they want, or to claim their share in case of marital conflict.

\section{Table 2: Name in which land titles are registered}

\begin{tabular}{llllll}
\hline & $\begin{array}{l}\text { Own } \\
\text { Name (\%) }\end{array}$ & $\begin{array}{l}\text { Spouse's } \\
\text { Name }(\%)\end{array}$ & $\begin{array}{l}\text { Couple's } \\
\text { Name (\%) }\end{array}$ & $\begin{array}{l}\text { Children’s } \\
\text { Name (\%) }\end{array}$ & Total (\%) \\
\hline Male & $151(85)$ & $6(3)$ & $12(7)$ & $8(5)$ & $177(100)$ \\
Female & $48(51)$ & $26(27)$ & $16(17)$ & $5(5)$ & $95(100)$ \\
\hline Total & $199(73)$ & $32(12)$ & $28(10)$ & $13(5)$ & $272(100)$
\end{tabular}

Data source: UCC and sample household survey

In a follow up group discussion, various reasons were given by men and women explaining why women register their lands in their husbands' names. The man is seen as the head of the family. In attempts to avoid disputes with possible breakup of the marriage, and to accord respect to their husbands, women register the lands they buy in the names of their husbands. Men on the other hand outlined the fact that litigation issues associated with land problems and the pride women felt to see their husbands in possession of valuable assets make some women register their land in their husband's name.

In Figure 2, the various sources by which individual respondents got to know about the intended sale of the lands that they purchased are represented. The majority of respondents heard about the sales through a friend or family members. The means by which a potential land owner gets to know about the sale of land could influence the negotiation 
Ogirisi: a new journal of African studies vol 92012 process used in acquiring the land. Within the land market's own frame of reference for functionality, there is the assumption that the market is accessible and information is available to all, although Tilley (2005) says that this assumption is not always true.

The land market is an overwhelmingly internal one and access to information is segmented and truncated. Much of the available land for sale is in fact transacted through an internal market based on word of mouth and through a network of "insiders", thereby further closing out new entrants.

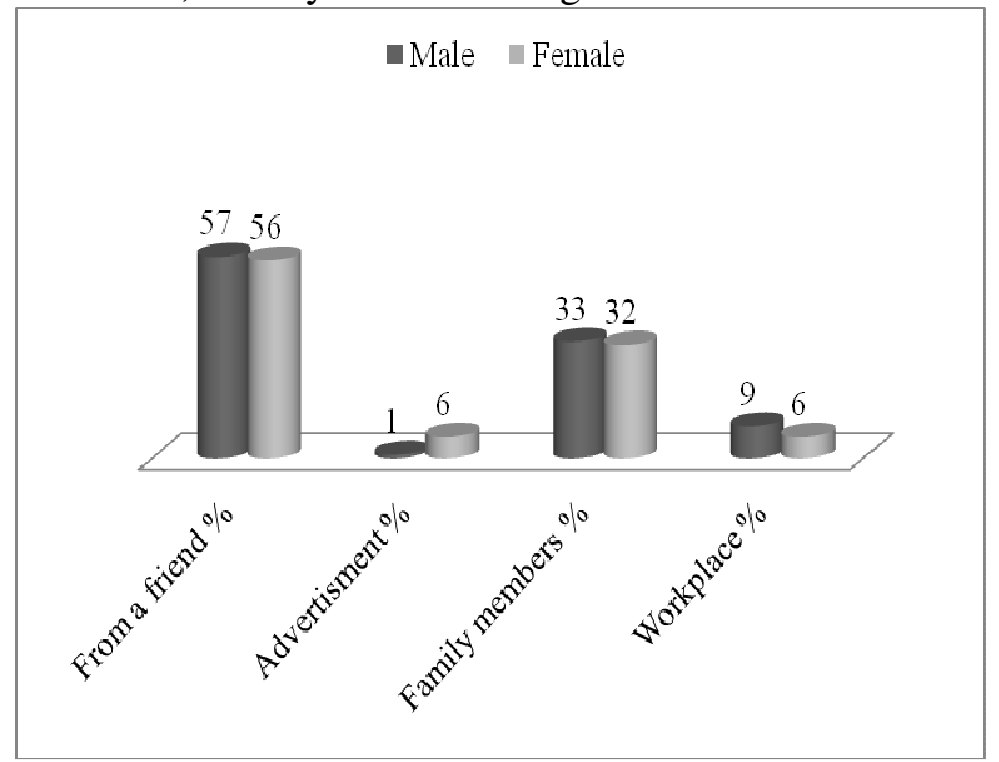

Figure 2: Source of information about the sale of land Data source: Field Survey, January-July 2009

It is evident that the land market, as it is currently constituted, is essentially a closed circuit that remains the preserve of the few who are capital and information-resourced, and who are part of the network of landowners who understand and determine the 'rules of the game'. In this sense, because more lands are controlled by men, men are more likely to hear 
about the sale of land from their fellow men than women. This would influence the number of women and men who acquire land. This would even influence the process of the negotiation. This is because, should a friend inform a colleague about the sale of a plot, it would be likely the friend would go with the colleague land buyer as an intermediary between the land seller and the friend. Only a few respondents, mostly women, got to know that their lands were being sold through public advertisement.

Figure 3 shows the distribution of land sellers in the study areas. Most of the respondents bought their lands from community/family heads. Most of the community and family heads who sell these lands are male. In a research by Gough and Yankson (2000) in peri-urban Accra, the majority (84\%) of land owners acquired their lands either from a chief or family head and the remaining (16\%) of respondents, obtained their plots from previous plot acquirers who probably acquired extra plots for speculative purposes. In the research result shown in Figure 8, women respondents who bought lands from community heads outnumbered that of the men. More men had also bought most of the lands from individual fellow men who had probably obtained extra plots for speculative purposes.

The gender implication for this result is that the number of women land owners is very insignificant. Only two plots of lands were bought from individual females as against 65 plots obtained from individual males. This is a confirmation of existing literature that most lands are in the control of men although some women might have lands but decide not to sell them. Tsikata (2009) had confirmed that patriarchy had affected women's ownership, access to and control of land in traditional rural societies. From Tsikata's report, one can conclude that control of land by women in urban areas is not significantly different from what pertains in the traditional rural areas. This has resulted in more males being in 
Ogirisi: a new journal of African studies vol 92012 possession of land. To Lastarria-Cornhiel (1997), in both matrilineal and patrilineal societies in Africa, land is predominantly allocated to males and transferred intergenerationally to males - to nephews in matrilineage and sons in patrilineage.

Another implication of men selling more land could mean that considering the high cost of land, it means men are making money out of land sales. This further concentrates resources in the hands of men and thereby widens the gender gap in wealth. On the other hand, some women may also face difficulty in buying from the community or family heads. Most women would have to look in the direction of men to lead them to negotiate for their lands.

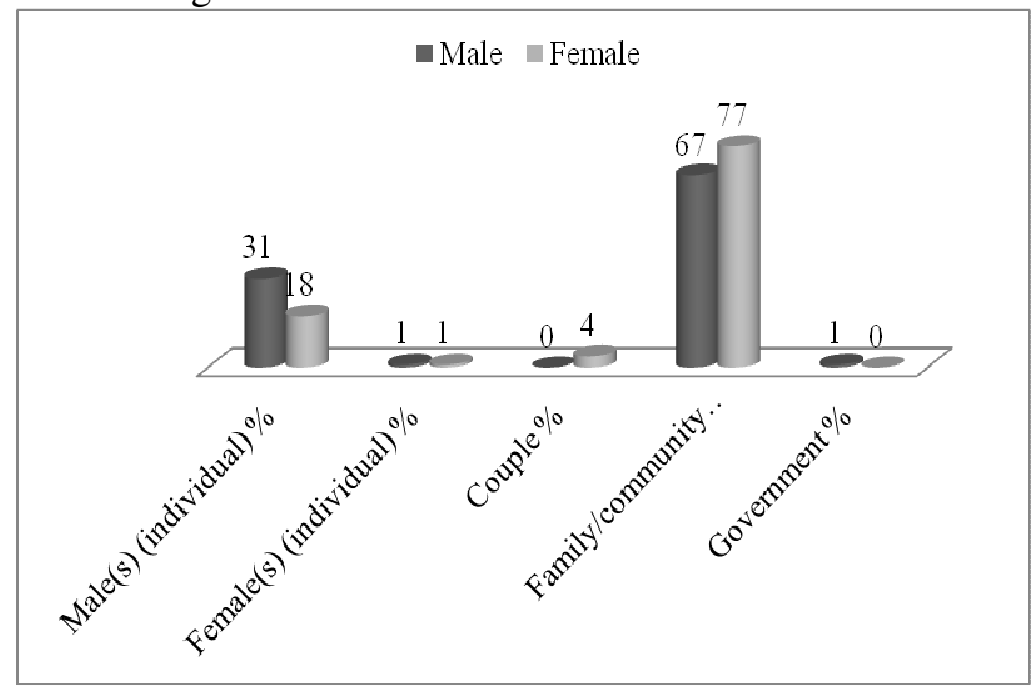

Figure 3: Distribution of land sellers in the Metropolis Data source: Field Survey, January-July 2009

Figure 4 shows the different ways and means adopted by various respondents to negotiate for their lands. Negotiating for land is one area that is very critical to the acquisition of land and usage. From the results, many of the male 
respondents negotiated for their lands alone as against their female counterparts who did it with male figures. Gough and Yankson (2000) found out in peri-urban Accra that rather than would-be land acquirers approaching the chief and elders or family heads, two-thirds of their respondents went through an intermediary as their respondents felt this would increase their chances of obtaining a plot at a more favourable price. The intermediaries were mostly friends and relatives. It can be noted that in peri-urban Accra, the main reason land acquirers went through intermediaries to obtain land was to get the plots of lands at a favorable price. Gough and Yankson did not indicate whether there is a gender difference in resorting to intermediaries.

The results in Figure 4 indicate that more women go through intermediaries, who are mostly male individuals, to obtain their lands. Many reasons were given for this. Basically, in the Cape Coast metropolis, respondents did not go with intermediaries in order to obtain the lands at favourable prices as indicated by Gough and Yankson (2000). In a focus group discussion among men and women, participants agreed that women wanted to seek the company of men to negotiate for land because of security reasons. Women might not know whether they are buying from the right owners or not.

A land broker attested to this by giving his experience. A woman came to him to buy a piece of land. After a short discussion, the woman said she would come back the next day. The next day, she came with a man who the land broker realized later was not her husband. The woman thought she could be cheated and this made him to bring a man to help in the negotiation process. The act of some land brokers cheating women in land negotiations were confirmed by respondents in the focus group discussions where the respondents agreed that 
Ogirisi: a new journal of African studies vol 92012 sometimes land brokers tended to sell land to women at a higher price.

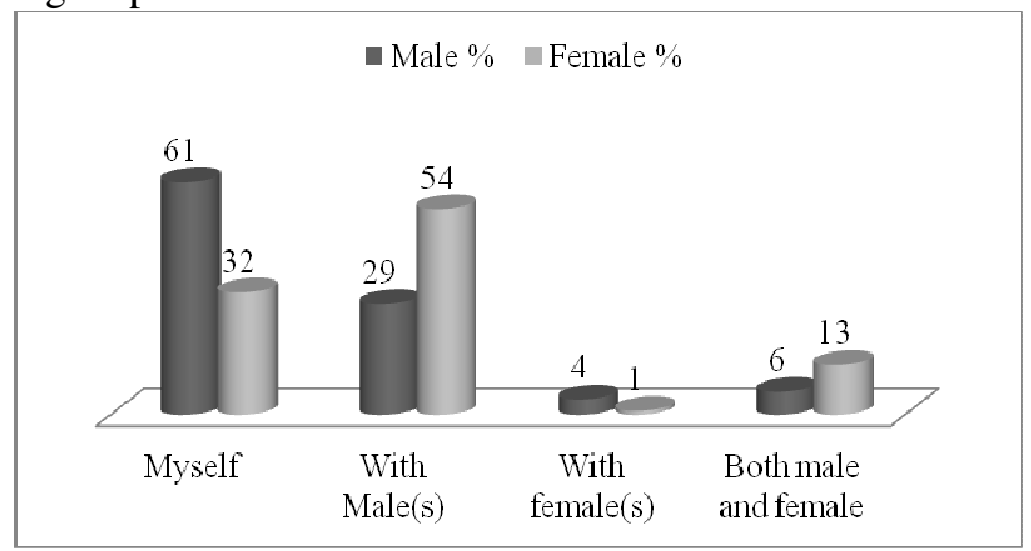

\section{Figure 4: Mode of land negotiation by respondents}

Data source: Field Survey, January-July 2009

Sometimes, women tend to look for men to face their fellow men to negotiate for land. The women's group discussants explained that sometimes the litigation issues associated with land acquisition makes women look in the direction of men to negotiate for them. Court cases associated with land issues make the women to ask the men to help them obtain their lands so that in case of court issues, the man can help the woman to fight for her land.

Sarpong (2006), Bortei-Doku (2002), Ruenger (2006) and Kwapong (2008) have stated that males have always been in control of land and all land matters in the society, both in colonial and post-colonial periods. These include decisions taken on land issues, which include the allocation of land to people in the society or family. This male domination in land matter restricts women's land rights in favour of men. From the reasons given by both men and women in the various focus group discussions as to why women go with male intermediaries to obtain their lands, it would not be far from 
right to conclude that some women still feel that land issues are still in the male domain.

The gender implication here could be that although men and women have equal legal rights to acquire land, the findings of this study show that women may find it more difficult to acquire land than men. Furthermore, women depending on men for land acquisition may further reinforce the perception of women as a weaker sex who should not claim equality with men. This is affirmed by the findings of Duncan and Brant (2004) from the Volta Region. Men strongly dominated decision-making processes and leadership in the region. They were seen as natural leaders, whereas women were considered to be too weak and vulnerable to be good leaders or major decision-makers. These perceptions down played the important roles played by women in the Volta Region, often placing them in the background in decisionmaking and their capabilities in becoming successful leaders and major decision-makers.

Table 3 shows the greatest concern of respondents in the land acquisition process. The concerns are of different categories. Although there are various concerns given by respondents, the most widely shared concern is trustworthiness of landowners. This is because there are lots of land disputes all over the country especially in urban areas as a result of multiple sale of land. This leads to the employment of land guards in some parts of the cities. There are several litigation cases around land. As a result of the problems associated with land ownership, most land buyers fear that they might be duped by land sellers. This is a great concern for respondents in negotiating for their lands. In addition to this concern, more women than men were also concerned about the cost of the land. Other reasons mentioned by respondents in the women focus group discussion included that some of the land sellers might inflate the price of the lands for women buyers. Women 
Ogirisi: a new journal of African studies vol 92012 were also concerned about the cost, as they might not have as much money as the men.

Table 3: Basic concerns in land negotiating

\begin{tabular}{llll}
\hline Concern & Male (\%) & Female (\%) & $\begin{array}{l}\text { Total } \\
(\%)\end{array}$ \\
\hline Trustworthiness of landowners & $122(76)$ & $62(74)$ & $175(75)$ \\
High cost of land & $16(10)$ & $13(15)$ & $29(12)$ \\
Unclear negotiation process & $3(2)$ & $3(4)$ & $6(2)$ \\
Reliance on others & $1(1)$ & $2(2)$ & $3(1)$ \\
Long negotiation process & $19(12)$ & $4(5)$ & $23(9)$ \\
\hline Total & $161(100)$ & $84(100)$ & $245(100)$ \\
\hline
\end{tabular}

Data source: Field Survey, January-July 2009

ISSER (2005) found out that migrants have difficulty in accessing land for construction in peri-urban areas due to inflated land prices. But generally, there is no discrimination based on gender, age, and religion in accessing peri-urban lands. This is mainly due to the fact that there is a land market and price is the real determinant of land access in peri-urban settlements. The conclusion that the system of acquiring land in peri-urban Ghana is nondiscriminatory because it is based on affordability is made with some level of caution. For instance, Amanor (2001) notes that in matrilineal areas of Ghana where women have rights to inherit land, the changing structure of the family and the effects of economic pressures are impacting negatively on women's access to land. He adds that matrilineal land is becoming scarcer because men are alienating it to their children. As a consequence, women are suffering from declining access to land and have to rely on husbands for land. Nevertheless, the ISSER land survey suggests that women who have the financial resources could overcome these social and cultural barriers, thus, allowing them to access land. Should the lands become too expensive, a lot of women would not be able to get access to the lands. 
Table 4 represents the most basic factor that influenced respondents to buy their lands. Most of the respondents bought their lands because of the town in which the land was located. People also bought lands because the lands were nearer to social amenities such as water, electricity and schools.

From the survey of selected houses in the study area, most of the respondents in the Menyamewu and Grace Hill residential areas said what influenced them to buy their plots was the neighbourhood. There are various reasons that would make people to buy land at a particular area or buy a particular piece of plot. As indicated by Gough and Yankson (2000), the most common reason given by new land-acquirers as was the lack of land disputes in the area. This illustrates how prevalent land disputes are and what a decisive role they. Other reasons given included: being near to family, a peaceful place, and near friends. The cost of plots seemed not to be a major factor in deciding where to buy land.

Table 4: The most influential factor for acquiring land.

\begin{tabular}{llll}
\hline Basic influence & Male & Female & Total \\
\hline Nature of the land & $28(17)$ & $16(19)$ & $44(18)$ \\
Cost & $15(9)$ & $7(8)$ & $22(9)$ \\
Size & $2(1)$ & $2(2)$ & $4(2)$ \\
Nearness to social amenities & $35(22)$ & $13(16)$ & $48(20)$ \\
Neighbourhood & $14(9)$ & $9(11)$ & $23(9)$ \\
Town & $29(18)$ & $22(26)$ & $51(21)$ \\
The quality of the land & $2(1)$ & $0(0)$ & $2(1)$ \\
Commercial value of land & $6(4)$ & $6(7)$ & $12(5)$ \\
Other & & & \\
& $30(19)$ & $9(11)$ & $39(15)$ \\
\hline Total & $161(100)$ & $84(100)$ & $245(100)$ \\
\hline Source
\end{tabular}

Source: Field Survey, January-July 2009

In the study area on the other hand, people were also influenced by the town in which the land was located. The size of the plots seemed not to be a major factor in deciding whether to buy a plot or not. The kind of buildings located at 
Ogirisi: a new journal of African studies vol 92012 Grace Hill and Menyamenwu were mostly storey buildings with walls and gates around the houses. Most of the landowners there were mostly men. In the Abubonku and Mpeasem residential areas the residents were middle income earners (their salaries ranged from 200 - 400 Ghana cedis). Lands for farming activities in the Metropolis were insignificant. People therefore did not consider the quality of the land before buying land. Since most respondents were interested in using the land for residential purposes, certain factors like its commercial value or the fertility of the land did not matter to them.

Figure 5 is showing the challenges faced by respondents throughout the land acquisition process. Before the advent of this research, I had assumed that women might face a lot of challenges in acquiring land for various uses. The research on the other hand has shown otherwise. In a follow up group discussion, women attested to the fact that they face no challenges in acquiring land as long as the land was acquired the genuine way.

When it comes to the various challenges faced by respondents in the purchase of their lands, the majority of the respondents did not face any challenge in acquiring their land. On the other hand, those who faced challenges such as the high cost of the land, the transparency of the transaction, certainty of land ownership and litigation associated with land, were mostly women. In a situation of speculation, the high and rising cost of urban lands might deter more from buying land in the metropolis. As indicated by Duncan and Brant (2004), it was easier for men to buy land due to the fact that traditionally men had the right to own land, and also men were richer than women. As a result of the better financial standing of men, more men would continue to buy more land. Women would continue to be dependent on men and the gender inequalities would continue to exist in access to and control over land. 


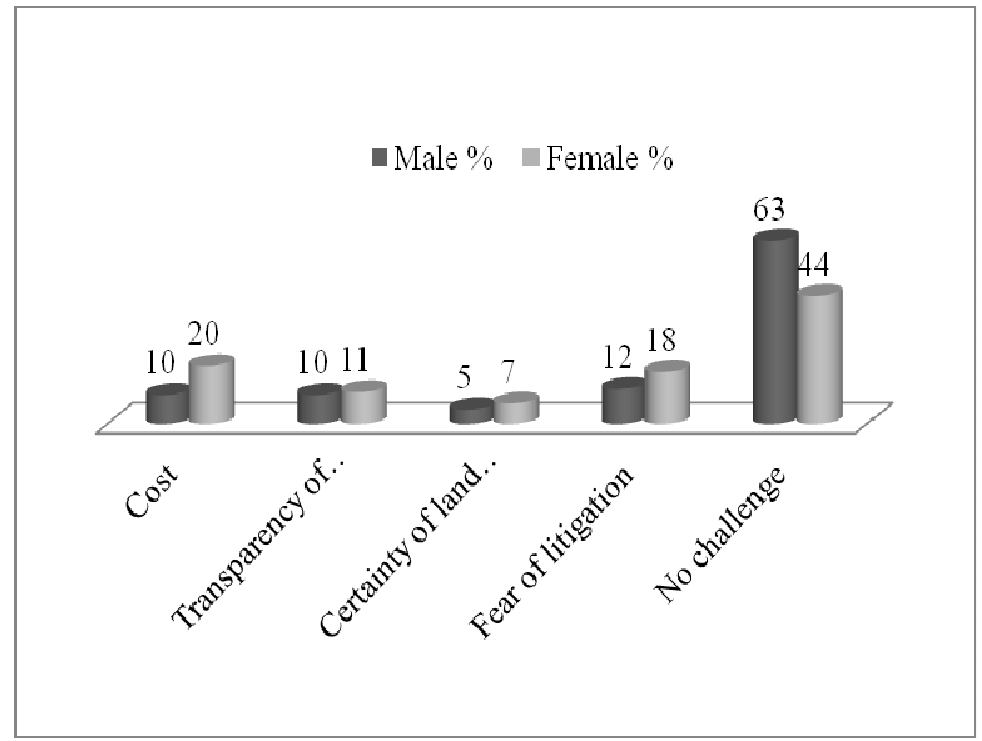

Figure 5: Challenges encountered in acquiring land Data source: Field Survey, January-July 2009

Figure 6 presents intended land use of UCC respondents who do not own land yet but are planning to own one in future. The majority of future landowners said they would like to buy land for residential purposes.

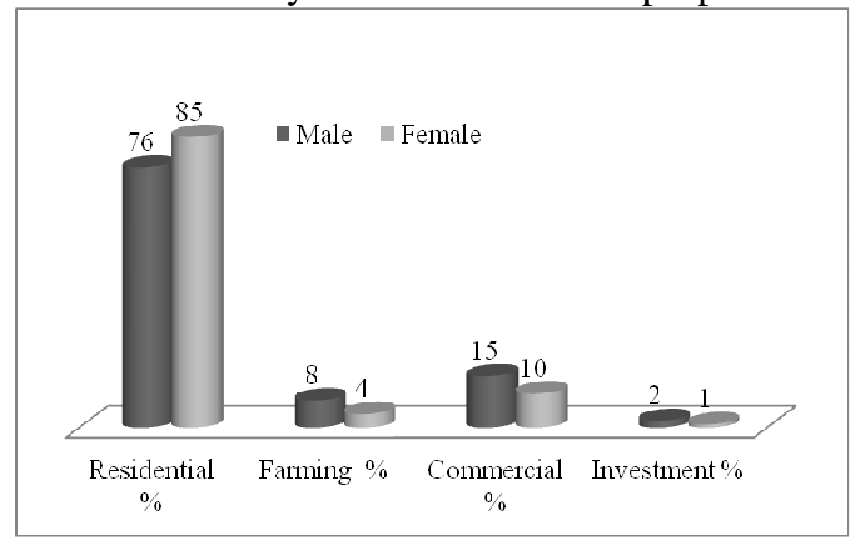

Figure 6: Gender differences in future land use by respondents 
Ogirisi: a new journal of African studies vol 92012

Data source: Field Survey, January-July 2009

\section{Conclusions and Recommendations}

From the survey, both men and women acquired most of their land through purchase as compared to inherited lands. The research also found out that more women than men had registered their lands. A large proportion of the lands bought by females have been registered in the names of their spouse or jointly with spouses. More women go through intermediaries, who are mostly male individuals, to obtain their lands. Based on the above conclusions, land banks should be established at the Lands Commission to help women purchase lands more easily. This will eliminate the middlemen and well as the hustle in negotiation and the fear of being duped. Again, it will simplify the title registration process and probably encourage more women to register lands in their own names.

*Eva Seraphim Tandoh Quansah is a Lecturer in the Department of African Studies, University of Cape Coast 


\section{References}

Agarwal, B. (1994). Gender and land rights revisited: Exploring new prospects via the state, family and market. Journal of Change, 3(1), 184-224.

Amanor, K. S. (2001). Land, labour and the family in southern Ghana: A Critique of Land Policy under Neoliberalization. Uppsala: NordiskaAfrikainstitutet.

Baden, S., Green, C., Otoo-Oyortey, N. \& Peasgood, T. (1994). Background paper on gender issues in Ghana. Report prepared for the West and North Africa Department, Department for Overseas Development (DFID), UK. Bridge Development-Gender, Report No. 19. Retrieved June 24, 2009 from http://www.fig.net/pub/proceedings/nairobi/waiganjongugi-TS6-2.pdf

Bortei-Doku E. A. (2002). "Behind the norms: Women's access to land in Ghana" In The dynamics of resource tenure in West Africa. London: IIED.

Duncan, B. A. \& Brants, C. (2004). Access to and control over land from a gender perspective. A study conducted in the Volta Region of Ghana. Accra: The Printers Press.

Gough, K. V \& Yankson, W. K. (2000). Land markets in African cities: The case of peri-urban Accra, Ghana. Urban Studies, 37(13), 2485-2500.

IFAD. (2001). Rural poverty report: The challenge of ending rural poverty. London: Oxford University Press.

ISSER. (2005). Household questionnaires survey, July 2005. Legon: University of Ghana.

Kameri-Mboti, P. (2005). Land tenure, land use and sustainability in Kenya: Towards innovative use of property rights in wildlife management. International Environmental Law Research Centre. Geneva, 
Ogirisi: a new journal of African studies vol 92012

Switzerland. Retrieved February 6, 2009 from http://www.capri.cgiar.org/wp/..\%5Cpdf\%5Cbrief_land05.pdf

Kwapong, O. A. T. F. (2008). The most affected in land issues Women, migrants, urban dwellers, youth and PLWHAs. International Journal of Rural Studies, 15(2). Retrieved December 6, 2009 from www.ivcs.org.uk/IJRS

Lasterria-Cornhiel, S. \& Garcia, F. (2009). Gender and land rights: Findings and lessons from country studies. FAO Corporate Document Repository. Retrieved from www.fao.com

Lastarria-Cornhiel, S. (1997). Impact of privatization on gender and property rights in Africa. World Development, 25(8), 1317-1333.

Ntege, H. (1993). Women and urban housing crisis: Impact of public policies and practices in Uganda. Economic and Political Weekly, 28(44), 46-62.

Nzioki, A. (2009). The Effect of land tenure on women's access and control of land in Kenya. Retrieved May 10, 2009 from www.jstore.org/stable/151481

Quarcoopome, S. S. (1992). Urbanization, land alienation and politics in Accra. Institute of African studies Research review, 8(1\&2) pp 40-54.

Qvist, E. (1995). Women's access, control and tenure of land, property and settlement. Retrieved March 3, 2009 from http://www.sli.unimelb.edu.au/fig7/Brighton98/Comm7Pa pers/TS26-Qvist.html

Ruenger, M. (2006). Governance, land rights and access to land in Ghana - A development perspective on gender equity. Promoting land administration and good governance regional conference, Accra, Ghana, March 811. Retrieved December 14, 2008 from http://www.fig.net/pub/accra/papers/ts01/ts01_02_ruenger. pdf 
Quansah: Land Tenure System \& Women's Access to Land

Sarpong, G. A., (2006). Improving tenure security for the rural poor Ghana - Country case study. LEP Working Paper No. 2. Workshop for Sub-Saharan Africa. Retrieved May 28, 2009 from

ftp://ftp.fao.org/docrep/fao/010/k0783e/k0783e00.pdf

Sarpong, P. (1974). Ghana in Retrospect: Some aspects of Ghanaian culture. Accra: Ghana Publishing Company.

Tilley, S. (2005). Why do the landless remain landless? Surplus people project (SPP), Land Research Action Network, South Africa. Retrieved on March 20, 2010 from http://www.landaction.org/display.php?article $=366$

Tsikata, D. (2009). Gender, land and labour relations and livelihoods in Sub-Saharan Africa in the era of economic liberalization: Towards a research agenda. In Feminist Africa land, Labour and gendered livelihoods. African Gender Institute, University of Cape Town, South Africa. 